\title{
Reviewing assertiveness level of elite male and female Athletes in Different Sports Branches
}

\author{
Özlem Keskin ${ }^{1}$ \\ Ayşe Demir ${ }^{2}$ \\ Buket Şenol $^{3}$
}

\begin{abstract}
The purpose of this research was to review the assertiveness levels of elite level athletes who study in İstanbul Aydın University and play different sports. For this purpose, the survey model was used in the study. A total of 121 students including 36 female (age average $x=20,11 \pm 1,83$ ) and 85 male (age average $x=20,34 \pm 2,47$ ) volunteered for this study. Rathus Assertiveness Schedule (RAE) that was developed by A.S Rathus (1973) was used as data collection tool to determine the assertiveness levels of participants (Voltan 1980). Adaption works for Turkish of this schedule was performed by Nilüfer Voltan Acar (1980). Independent T-test and One Way ANOVA Test in SPSS 24.0 packaged software were used in statistical analyses of the data obtained. It was found at the end of the research that the assertiveness level of 19 students is at timidity level, the assertiveness level of 102 students is at an aggressive level. While there were no statistically significant differences in variables of gender, branch, income level and educational background of the parent; there was found statistically significant difference by evaluation based on age ranges.
\end{abstract}

Keywords: Assertiveness; athlete; student; university; elite.

\section{Introduction}

Assertiveness can be defined in scientific language as 'expressing oneself. In the broadest sense, assertiveness is being expressed the ideas, desires, and beliefs without overriding or feeling guilty or anxiety (Rychta, 2004; Gacar and Coşkuner, 2010). Namely, the person says directly his feeling and thought honestly. Assertiveness concept must not no mistake for aggression (Maciaszczyk, 2011). While the aggression is defined as getting the desired by ignoring the rights of others, assertiveness concept considers the rights of others.

Assertiveness is a characteristic feature, as well as a behavior pattern, uses honesty as the base in human relations. Besides, it is a crucial communication skill. Therefore, the general run of the studies on assertiveness has analyzed the effect of assertiveness on human affairs (Anderson and Bushman, 2002; Eraslan, 2015; Bavl1, 2009). Individuals with low levels of assertive behavior are either passive or aggressive in relationships (Tekin et al., 2009). Thus, it can be confirmed that the people with assertiveness effectively express themselves in society (Efe et al., 2008)

\footnotetext{
1 Assist. Prof. Dr., Kocaeli University, Faculty of Sport Sciences, ozlemnht@,hotmail.com

${ }^{2}$ Research Assistant, İstanbul Aydın University, Faculty of Sport Sciences, aysedemir@aydin.edu.tr

${ }^{3}$ Graduate student, Kocaeli University, Faculty of Sport Sciences, snlbuket@gmail.com
} 
Keskin, Ö., Demir, A., \& Șenol, B. (2018). Reviewing assertiveness level of elite male and female Athletes in Different Sports Branches. Journal of Human Sciences, 15(4), 1924-1932. doi:10.14687/jhs.v15i4.5319

The person can acquire assertiveness trait. One of the most effective methods for a person to acquire assertiveness is participating in physical training and sports activities (Husman and Silva, 1984). Many of the studies in literature reported that physical training and sport activities have positive effects on improving the assertiveness level (Çam et al., 2014; Kırımoğlu et al., 2009; Öztürk et al., 2007; Yalçnkaya et al., 2002; Kaya et al., 2010; Efe et al., 2008). In the sports domain, researchers revealed significant differences between assertiveness of athletes and non-athlete students. Also, Büyükyazı et al. (2003) concluded that sports activity has an effect on assertiveness. Even people who exercise three times per week are more assertive than those who exercise once per week (Nojedehi, et al. 2015).

Assertiveness has the meanings of; "being initiative," "openly self-assertive," "behaving actively". Assertiveness is not a universal feature. It changes up to the person and the situation. Individual differences and cultural characteristics are important to behave assertively (Sucan et al., 2015; Ekinci et al. 2013). Especially the age of the person is an important factor for assertiveness level. University studentship period that takes 17-25 age range is a significant period in the improvement of students' personality as well as the assertiveness trait is pretty important in those periods. In 17-25 age range, students try to make intimacy and adapt to their environments while they experience the differences between aggressive, passive and assertive behaviors. They also experience the contribution of these behaviors to their lives (Gündoğdu, 2012). Starting to university education that brings individual confidence and responsibility necessitates both orienting oneself to a new environment by coming from different cultures and making independent decisions in case of necessity. These are the factors that are effective on assertiveness level of the individual (Ylmaz, 2001).

This study that we conducted in the light of this information aimed to review the assertiveness level of male and female elite athletes in different sports branches in İstanbul Aydin University.

\section{METHOD}

\section{Research Group}

A total of 121 students including 36 female (age average $x=20,11 \pm 1,83$ ) and 85 male (age average $x=20,34 \pm 2,47$ ) volunteered for this study. The population is composed of athletes study at İstanbul Aydın University and play different sports branches at an elite level.

\section{Data Collection Tool}

Rathus Assertiveness Schedule (RAE) that was developed by A.S Rathus (1973) was used as data collection tool to determine the assertiveness levels of participants (Voltan 1980). Adaption works for Turkish of this schedule was performed by Nilüfer Voltan Acar (1980). Rathus Assertiveness Schedule is composed of 30 questions and in the form of 6 points Likert Scale. It is scaled as $1=$ It never fits, $2=$ It does not fit much, $3=$ It does not quite fit, $4=$ It fits a bit, $5=$ It quite fits, $6=$ It perfectly fits. 1 st, $2 \mathrm{nd}, 3 \mathrm{rd}, 4 \mathrm{th}, 5 \mathrm{th}, 9 \mathrm{th}, 11 \mathrm{th}, 12 \mathrm{th}, 13 \mathrm{th}, 14 \mathrm{th}, 15 \mathrm{th}, 16 \mathrm{th}$, 17th, 19th, 23rd, 24th, 26th and 30th items in scale are graded by reversing. Other items are graded as they are. The points vary between- 90 and +90 . The participant gets point from each of the items between- 3 and +3 ( $-3=$ It never fits, $-2=$ It does not fit much, $-1=$ It does not quite fit, $+1=$ It fits a bit, $+2=$ It quite fits, $+3=$ It perfectly fits). With reference to the scores, the point between- 90 and +9 is evaluated as timid behavior; the point between +10 and +90 is evaluated as assertive behavior.

\section{Data Collection}

The survey model was used in the study. After the coverage of the research and the clarification of the questionnaire, the questionnaire was applied to the university students who were included in the research. 
Keskin, Ö., Demir, A., \& Șenol, B. (2018). Reviewing assertiveness level of elite male and female Athletes in Different Sports Branches. Journal of Human Sciences, 15(4), 1924-1932. doi:10.14687/jhs.v15i4.5319

\section{Data Analysis}

Average, standard deviation, frequency, and percentage transactions were applied to show the distributions of data obtained. The t-test was used in independent groups to specify the differences by gender and age range variables. The evaluations for income level, educational background of parents and sports branches were made via One Way ANOVA test. SPSS 24.0 packaged software analyzed the data.

\section{Results}

Table 1: Frequency and percentage values belong to gender, age ranges, training age range and sports branch

\begin{tabular}{ccc|c|} 
& & Frequency & Percent \\
\hline \multirow{2}{*}{ Gender } & Female & 36 & 29,8 \\
\cline { 2 - 4 } & Male & 85 & 70,2 \\
\hline \multirow{2}{*}{ Age Group } & $18-21$ & 89 & 73,6 \\
\cline { 2 - 4 } & $22-25$ & 32 & 26,4 \\
\hline \multirow{2}{*}{ Training age group } & $1-4$ years & 26 & 21,5 \\
\cline { 2 - 4 } & $5-8$ years & 50 & 41,3 \\
\cline { 2 - 4 } & $9-12$ years & 35 & 28,9 \\
\cline { 2 - 4 } & $13-16$ years & 10 & 8,3 \\
\hline \multirow{2}{*}{ Branches } & Individual & 50 & 14,9 \\
\cline { 2 - 4 } & Volleyball & 18 & 21,5 \\
\hline & Basketball & 27 & 26 \\
\cline { 2 - 4 } & Football & 26 & 21,3 \\
\hline
\end{tabular}

36 female and 85 male students participated in the research. 89 of them was in 18-25 age range; 32 of them was in 22-25 age range. General age average of participants was found as $20,27 \pm 2,29.18$ of them play volleyball, 27 of them play basketball, 26 of them play football and finally, 50 of them play individuals sports.

Table 2: Frequency and percentage values belong to income level and educational background of parents

\begin{tabular}{ccc|c|} 
& & Frequency & Percent \\
\hline \multirow{3}{*}{ Income Status } & Less than 2000 TL & 20 & 16,5 \\
\cline { 2 - 4 } & $2001-3000$ & 31 & 25,6 \\
\cline { 2 - 4 } & $3001-4000$ & 36 & 29,8 \\
\cline { 2 - 4 } & More than 4001 TL & 34 & 28,1 \\
\hline \multirow{2}{*}{$\begin{array}{c}\text { Educational } \\
\text { Background of } \\
\text { Mother }\end{array}$} & University & 16 & 13,2 \\
\cline { 2 - 4 } & High school & 43 & 35,5 \\
\hline & Secondary School & 35 & 22,3 \\
\hline
\end{tabular}


Keskin, Ö., Demir, A., \& Șenol, B. (2018). Reviewing assertiveness level of elite male and female Athletes in Different Sports Branches. Journal of Human Sciences, 15(4), 1924-1932. doi:10.14687/jhs.v15i4.5319

\begin{tabular}{ccc|c|}
\hline & University & 26 & 21,5 \\
\cline { 2 - 4 } $\begin{array}{c}\text { Educational } \\
\text { Background of } \\
\text { Father }\end{array}$ & High school & 51 & 42,1 \\
\cline { 2 - 4 } & Secondary School & 24 & 19,8 \\
\cline { 2 - 4 } & Primary School & 20 & 16,5 \\
\hline
\end{tabular}

Income levels of participants show high distribution (36 of them) between 3001-4000 TL. It was analyzed that high school education level was dominant for both educational background of the mother (43 persons) and educational background of the father (51 persons).

Table 3: Average and standard deviation values of points received from Rathus Assertiveness Schedule in terms of gender, branch, income level and educational background of parents

\begin{tabular}{|c|c|c|c|c|c|c|}
\hline & & $\mathrm{N}$ & Minimum & Maximum & Mean & $\mathrm{Sd}$ \\
\hline \multirow{2}{*}{ Gender } & Female & 36 & 5,00 & 49,00 & 20,38 & 11,03 \\
\hline & Male & 85 & $-, 15,00$ & 46,00 & 19,23 & 11,24 \\
\hline \multirow{4}{*}{ Branches } & Individual & 50 & 4,00 & 49,00 & 21,84 & 10,62 \\
\hline & Volleyball & 18 & $-3,00$ & 46,00 & 17,88 & 12,18 \\
\hline & Basketball & 27 & 2,00 & 34,00 & 17,66 & 8,15 \\
\hline & Football & 26 & $-, 15,00$ & 37,00 & 18,38 & 13,69 \\
\hline \multirow{4}{*}{$\begin{array}{l}\text { Income } \\
\text { Status }\end{array}$} & Less than $2000 \mathrm{TL}$ & 20 & $-15,00$ & 46,00 & 19,90 & 13,76 \\
\hline & $2001-3000$ & 31 & $-3,00$ & 37,00 & 19,19 & 8,70 \\
\hline & $3001-4000$ & 36 & $-3,00$ & 49,00 & 20,11 & 11,28 \\
\hline & More than $4001 \mathrm{TL}$ & 34 & $-6,00$ & 46,00 & 19,17 & 11,75 \\
\hline \multirow{4}{*}{$\begin{array}{l}\text { Educatio } \\
\text { nal } \\
\text { Backgrou } \\
\text { nd of } \\
\text { Mother }\end{array}$} & University & 16 & 2,00 & 40,00 & 17,68 & 10,63 \\
\hline & High school & 43 & 6,00 & 49,00 & 21,48 & 9,72 \\
\hline & Secondary School & 35 & $-3,00$ & 46,00 & 19,42 & 10,24 \\
\hline & Primary school & 27 & $-15,00$ & 46,00 & 17,85 & 14,33 \\
\hline \multirow{4}{*}{$\begin{array}{l}\text { Educatio } \\
\text { nal } \\
\text { Backgrou } \\
\text { nd of } \\
\text { Father }\end{array}$} & University & 26 & 2,00 & 46,00 & 20,26 & 10,63 \\
\hline & High school & 51 & $-6,00$ & 49,00 & 18,62 & 10,60 \\
\hline & Secondary School & 24 & $-15,00$ & 46,00 & 20,45 & 12,97 \\
\hline & Primary school & 20 & $-3,00$ & 38,00 & 20,05 & 11,51 \\
\hline
\end{tabular}

Total points vary between- 90 and +90 . The point between- 90 and +9 is accepted as timid; the point between +10 and +90 is accepted as assertive behavior. It is found at the end of this evaluation that 19 participants display timid behavior, 102 of them display assertive behavior. 
Keskin, Ö., Demir, A., \& Șenol, B. (2018). Reviewing assertiveness level of elite male and female Athletes in Different Sports Branches. Journal of Human Sciences, 15(4), 1924-1932. doi:10.14687/jhs.v15i4.5319

Table 4: Comparison of assertiveness levels of participants in terms of gender and age range variables

\begin{tabular}{lc|c|c|c|c} 
& $\mathrm{N}$ & Mean & $\mathrm{Sd}$ & $\mathrm{t}$ & $\mathrm{p}$ \\
\cline { 2 - 4 } Female & 36 & 20,38 & 11,03 & \multirow{2}{*}{, 523} & \multirow{2}{*}{0,60} \\
\cline { 1 - 4 } Male & 85 & 19,23 & 11,24 & & \\
\hline 18-21 ages & 89 & 20,65 & 11,26 & \multirow{2}{*}{2,474} & \multirow{2}{*}{$0,01^{*}$} \\
\cline { 1 - 4 } 22-25 ages & 28 & 15,17 & 9,85 & & \\
\hline
\end{tabular}

While there was no difference $(\mathrm{p}>0,05)$ by gender and age range variables, there were statistically significant differences $(p<0,05)$ by age range variable.

Table 5: Comparison of assertiveness levels of participants in terms of income level and educational background of parents

\begin{tabular}{|c|c|c|c|c|c|c|}
\hline & & $\begin{array}{l}\text { Sum of } \\
\text { Squares }\end{array}$ & df & $\begin{array}{l}\text { Mean } \\
\text { Square }\end{array}$ & F & Sig. \\
\hline \multirow{3}{*}{ Income Status } & $\begin{array}{l}\text { Between } \\
\text { Groups }\end{array}$ & 22,369 & 3 & 7,456 & \multirow{3}{*}{,059 } & \multirow{3}{*}{0,98} \\
\hline & $\begin{array}{l}\text { Within } \\
\text { Groups }\end{array}$ & 14893,135 & 117 & 127,292 & & \\
\hline & Total & 14915,504 & 120 & & & \\
\hline \multirow{3}{*}{$\begin{array}{c}\text { Educational } \\
\text { Background of } \\
\text { Mother }\end{array}$} & $\begin{array}{l}\text { Between } \\
\text { Groups }\end{array}$ & 295,344 & 3 & 98,448 & \multirow{3}{*}{,788 } & \multirow{3}{*}{0,50} \\
\hline & $\begin{array}{l}\text { Within } \\
\text { Groups }\end{array}$ & 14620,161 & 117 & 124,959 & & \\
\hline & Total & 14915,504 & 120 & & & \\
\hline \multirow{3}{*}{$\begin{array}{l}\text { Educational } \\
\text { Background of } \\
\text { Father }\end{array}$} & $\begin{array}{l}\text { Between } \\
\text { Groups }\end{array}$ & 81,559 & 3 & 27,186 & \multirow{3}{*}{,214 } & \multirow{3}{*}{0,88} \\
\hline & $\begin{array}{l}\text { Within } \\
\text { Groups }\end{array}$ & 14833,945 & 117 & 126,786 & & \\
\hline & Total & 14915,504 & 120 & & & \\
\hline
\end{tabular}

There was no statistically significant difference $(p>0,05)$ when the assertiveness scores were compared by income level and educational background of parents 
Keskin, Ö., Demir, A., \& Șenol, B. (2018). Reviewing assertiveness level of elite male and female Athletes in Different Sports Branches. Journal of Human Sciences, 15(4), 1924-1932. doi:10.14687/jhs.v15i4.5319

Table 6: Comparison the assertiveness levels of participants in terms of sports branches

\begin{tabular}{|c|c|c|c|c|c|c|}
\hline & & $\begin{array}{l}\text { Sum of } \\
\text { Squares }\end{array}$ & df & $\begin{array}{l}\text { Mean } \\
\text { Square }\end{array}$ & $\mathrm{F}$ & Sig. \\
\hline \multirow{3}{*}{ Branches } & $\begin{array}{l}\text { Between } \\
\text { Groups }\end{array}$ & 442,853 & 3 & 147,618 & \multirow{3}{*}{1,193} & \multirow{3}{*}{0,31} \\
\hline & $\begin{array}{l}\text { Within } \\
\text { Groups }\end{array}$ & 14472,652 & 117 & 123,698 & & \\
\hline & Total & 14915,504 & 120 & & & \\
\hline
\end{tabular}

There was no statistically significant difference $(\mathrm{p}>0,05)$ when the assertiveness scores were compared by sports branches.

\section{Discussion}

Assertiveness that is defined as the self-expression skill of the individual is an essential determinant of relations of the person with his environment. There are several factors affect this situation. According to the cultural structure of our society, it is expected men to be more assertive than women. However, there was not found a significant relationship between gender and assertiveness level. There are similar results in studies conducted for determining the assertiveness levels of university students. Hoşgör et al. (2016) could not find a significant difference between gender and assertiveness schedule point averages in the study conducted on university students study in the faculty of health sciences. In a similar vein, Eraslan (2015) reported that gender does not create a significant difference for assertiveness levels of students in the sports department of universities. Again, Uzuntarla et al. (2016) determined that gender has no significant effect on assertiveness levels of university students. These and many of studies in literature (Küçükkaragöz et al. (2013); Voltan-Acar et al. (2008)) show consistency with the findings of this research. Being taken a close interest in sports by both groups can be accepted as the reason for this circumstance. However, there are studies (Ekinci et al., 2013; Arslantaş et al., 2013; Karataş and Tabak, 2009) in literature report a significant relationship between gender variable and assertiveness level in different research groups. This difference can be based upon the socio-cultural differences between the groups.

According to the general expectation, being the educational background of parents high is effective on social, behavioral and emotional characteristics of children. It was found in this research that the educational status of mother and fathers has no statistically significant effects on assertiveness levels of participants. Uzuntarla et al. (2016), Kahriman (2005) and Yelmaz and Ekinci (2001) conducted studies on university students to determine their assertiveness levels and found no statistically effects. This result shows consistency with our research findings.

There was not found any statistically significant relationship between income level and assertiveness levels. However, Uzuntarla et al. (2016), Mollaoğullar1 and Alptuğ (2013), Yılmaz and Ekinci (2001) observed a statistically significant difference and emphasized that as the income level of parents increases, the assertiveness level increases as well. This research does not show a significant difference unlike the studies mentioned. More homogeneous distribution in the income level of parents in comparison with others may be the reason for this circumstance. Besides, being selected a group who study in private university due to the high income level of their families may be the other reason.

There was found a statistically significant difference between age ranges and assertiveness level total scores as well. Several studies in the literature report that there is no statistically significant effect of different age groups on assertiveness levels (Öztürk and Bayaz1t, 2016; Hoşgör et al., 2016; Çam et al., 2014). Some of the surveys found positive effects of age 
parameter on assertiveness. Kaya (2001) mentioned that the older students have higher assertiveness level in comparison with juniors. With reference to Uğur (1996), the assertiveness level of people who are 21 years and older and wrestlers who are in the 16-17 age group is higher than the assertiveness level of wrestlers in 13-15 age group. Similarly, it was concluded by Alagül (2004) that age groups are effective on assertiveness scores. These results show consistency with our research findings. Büyükyazı et al. (2003) pointed out that training may be effective to increase the assertiveness levels in median age groups and eld people.

Much as the findings are different from some of the points in literature, the findings generally show similarity with existing literature. Assertiveness levels of attendees do not vary by the sports branches. Assertiveness levels of attendees are at timidity level for 19 of them. 102 of the attendees display assertive behavior. Abakay et al. (2017) did not find any difference in assertiveness scores according to playing or not playing sports. Öztürk et al. (2007) mentioned that sports have effect on assertiveness level. With reference to this paper, the assertiveness levels of athletes are high. Therefore, the studies should be planned so as to be before and after starting to sports for enlarging the scope of the research. Moreover, it can be contributed to the literature by enlarging the scope of the research by attaching different variables and by reconnoitering in more varied sample groups.

\section{References}

Abakay, U., Alincak, F. and Ay, S. (2017). "Body Perception of University Students and Reviewing Assertiveness Levels". Journal of International Turkish Educational Sciences. $5(9): 12-18$.

Alagül, Ö. (2004). "The Relationship between Assertiveness and Body Perception of Athletes in Different Sports Branches". Postgraduate Thesis. Ege University Health Sciences Institute İzmir, 2004.

Anderson, C.A., Bushman, B.J. (2002). "Human aggression". Annual Review of Psychology, 53, 27-51.

Arslantaş, H., Adana, F., Şahbaz, M. (2013). "Analysis of Assertiveness Levels of High School Students by Specific Variables". Journal of Florence Nightingale Nursing 21 (2): 76-84.

Bavli, Ö. (2009). "Examination of the Relationships between Assertiveness Level and Injury Status of Budding Sportsmen". Firat University, Journal of Medical Health Sciences. 23(1), 7-19.

Büyükyazı, G., Saracaloğlu, A. S., Karadeniz, G., Çamlıyer, H., Çamlıyer, H. (2003). "Comparison of Sedentary and Veteran Athletes' Assertiveness Levels by Various Variables”. Journal of Gazi Physical Education and Sports Sciences. VIII (4), 13-24.

Çam, İ., Özçelik, İ. Y., Çetin, B., Salman, M. and Çekin, R. (2014). "Investigation of Assertiveness Levels of Students of Academy of Physical Education and Sports of Celal Bayar University based on Different Demographic Features". CBU Journal of Physical Education and Sports Sciences. 5(2), 46-51.

Efe, M., Öztürk, F., Koparan, Ş. and Şenışık, Y. (2008). "Social Competence Expectation of Volleyball Training in 14-16 Age Group Boys and the Effect of Volleyball Training on Their Assertiveness". Uludağ University, Journal of Faculty of Education. 21(1), 69-77.

Ekinci, M., Altun, Ö.Ş., Can G. (2013). "Stress management styles of nursing students and reviewing their assertiveness levels in terms of specific variables". Journal of Psychiatric Nursing 4(2), 67-74.

Eraslan, M. (2015). "Analysis of Assertiveness and Decision Making Styles of Students of Sports Department by Various Variables". Journal of Faculty of Education of Bartın University. $4(1), 214-223$. 
Keskin, Ö., Demir, A., \& Șenol, B. (2018). Reviewing assertiveness level of elite male and female Athletes in Different Sports Branches. Journal of Human Sciences, 15(4), 1924-1932. doi:10.14687/jhs.v15i4.5319

Erşan, E., Doğan, O. and Doğan, S. (2009). "Sociodemographic Evaluation of Aggression Levels of Students of Physical Education and Sports High School". Cumhuriyet Medical Journal. 31(3), 231-238.

Gacar, A. and Coşkuner, Z. (2010). "Analysis of the Level of Assertiveness of Wrestlers In Terms Of Specific Variables”. NWSA: Sports Sciences. 5(3), 195-203.

Gündoğdu, R. (2012). "Impact of Creative Drama-Based Assertiveness Program on Assertiveness Skill of Psychological Counselor Candidates". Educational Sciences in Theory and Practice. 12(2), 677-693.

Hoşgör, H., Kurtuluş, S.A., Hoşgör, D.G., Söyük, S. (2016). "Determination of Assertiveness Levels of University Students: Faculty of Health Sciences Case". Journal of Academic Social Investigations. 4(32), 430-441.

Husman, B.F., Silva, J.M. (1984). "Aggression in sport: definitional and theoretical considerations", In J.M. Silva, R.S. Weinberg (eds.) Psychological foundations of sports. Champaign: Human Kinetics.

Kahriman, İ. (2005). "Examination Of Self-Esteem And Assertiveness Levels Of Students Of Health High School Of Karadeniz Technical University In Terms Of Some Variables". Journal of Nursing High School of Cumhuriyet University. 9(1), 24-32.

Karataş, S., Tabak, N. (2009). "Examination of Assertiveness Levels of Pre-school Teacher Candidates in Terms of Some of the Socio-Demographic Features”. Journal of Uşak University Social Sciences. 2(2), 143-159.

Kaya, A. M., İnan, T., and Kelleci, M. (2010). "Investigation of the Relationship Between Assertiveness and Physical Activity Levels of High School Students of Physical Education And Sports Department of Cumhuriyet University". NWSA: Sports Sciences. 5(3), 218226.

Kaya, Z. (2001). "A Study on the Comparison of Degree of Assertiveness and Trait Anxiety of Vocational High School Students". Institute of Educational Sciences of Dokuz Eylül University, İzmir, 2001.

Kırımoğlu, H., Kepoğlu, A., Dereceli, Ç., Parlak, N. and Tozoğlu, E. (2009). "Examination of Assertiveness Levels of 2nd Stage Students in Primary Education in Terms of Sports Participation (Ankara Province- Elmadă̆ District Case)". Atatürk University, Journal of Physical Education and Sports Sciences. 11(1), 7-15.

Küçükkaragöz H, Canbulat T, Akay Y. (2013). "Assertiveness Level of Teacher Candidates and Their Communication Skills". Mustafa Kemal University, Journal of Social Sciences Institute. 10(22), 123-133.

Maciaszczyk, P. (2011). Agresywność an asertywność młodocianych sprawców przestępstw [Juvenile offenders' aggressiveness and assertiveness]. Tarnobrzeg: Publishing House of Professor S. Tarnowski State Higher Professional School.

Mollaoğullar1, H., Alptuğ, E.C. (2013). "Examining The Self-Esteem And Assertiveness Levels Of University Students Who Do Or Do Not Play Sports". Muğla Sttk1 Koçman University, Journal of Social Sciences Institute. 31,135-143.

Nojedehi, A., Aghdasi, M. T., Shojaei, M. (2015). "The Effect of the Skill level, Sports Disciplines, and gender on Karatekas' assertiveness (Kata and Kumite)". International Journal of Sports Studies. 5 (4), 470-474.

Öztürk, A., Bayazıt, B. (2016). "Examination of Assertiveness Levels and Problem-Solving Skills of Students of Physical Education and Sports (Kocaeli University Recreation Department Case)". Journal of Academic Social Investigations, 4(25), 332-340.

Öztürk, F., Efe, M. and Koparan, Ş. (2007). "Effect of Handball Works on Social Competence Expectation and Assertiveness in 14-16 Age Group of Girls". Journal of Hacettepe Sports Sciences. 18(4), 147-155.

Rathus, S. A. (1973). “A 30 Item Schedule for Assessing Assertive Behavior”. Behavior Therapy. 398-406. 
Rychta, T. (2004). Agresta w sporcie. Definite I rodzaje agresji [Aggression in the sport. Definitions and aggression types]. In: A. Rejzner (ed.): Agresja w szkole, spojrzenie wieloaspektowe [Aggression in school, a multi-faceted look]. Warszawa [Warsaw]: High School of Pedagogy. Society for the Popularization of Culture and Science.

Sucan, S., Turan, M. B., Pepe, O., Doğan, D. (2015). "The Relationship with Self Esteem Between Assertiveness Levels of Sub-Elite In-Door Soccer Players". International Journal of Science Culture and Sport. Special Issue 3, 156-162.

Tekin, G., Amman, M. T. ve Tekin, A. (2009). "The Effect of Physical Exercise Made in Leisure Time on Depression and Assertiveness Levels of University Students". Journal of International Human Sciences. 6(2), 148-159.

Uğur, G. (1996). "Assertiveness and Body Perception in University Students". Postgraduate Thesis. Ege University Social Sciences Institute, İzmir, 1996.

Uzuntarla, Y., Cihangiroğlu, N., Ceyhan, S., Uğrak, U. (2016). "Analysis of Assertiveness Levels of University Students". TAF Preventive Medicine Bulletin. 15(2), 98-104.

Voltan, N. R. (1980). "Validity\&Reliability Study of Assertiveness Inventory". Journal of Psychology, 10: 23-25.

Voltan-Acar, N., Arıcıoğlu, A., Gültekin, F., Gençtanırım, D. (2008). "Investigation of the Assertiveness Level of University Students". Journal of Faculty of Education of Hacettepe University. 35, 342-350.

Yalçınkaya, M., Silkü, A. ve Özkütük, N. (2002). “Assertiveness Skills of University Students and Their Interests in Sports". Jornal of Ege Education. 1(2), 147-154.

Yilmaz, S., Ekinci, M. (2001). "The Relationship Between Self - Esteem And Assertiveness Level In Nursing School Students". Nursing High School Journal of Atatürk University. 4(2), 1 10 . 